\title{
PENGELOMPOKKAN HASIL SURVEI DOSEN SELAMA KEGIATAN PEMBELAJARAN DARING ( STUDI KASUS STMIK KAPUTAMA)
}

\author{
Hernika W. Nainggolan ${ }^{1}$, Indah Ambarita ${ }^{2}$, Siswan Syahputra ${ }^{3}$ \\ 1,2,3 Program Studi Sistem Informasi \\ STMIK KAPUTAMA \\ 1hernikanainggolan@gmail.com, ${ }^{2}$ yesnovada@gmail.com , ${ }^{3}$ siswansyahputra90@gmail.com
}

\begin{abstract}
Learning that is usually done offline is now learning at home or online using various applications such as classroom, zoom, google doc, google forms, whatsapp groups and teacher rooms. Distance learning can reduce the risk of spreading the corona virus and in accordance with the circular issued by the Ministry of Education and Culture for online learning. As teaching staff, lecturers are expected to continue to make efforts to improve and improve the quality of lectures through various planned programs. Lecturers are required to be able to design and design online learning that is light and effective. Lecturers are required to be able to design and design online learning that is light and effective. Thus, the implementation of online learning at STMIK Kaputama Binjai must be monitored and evaluated so that the quality of education is maintained. Evaluation of online learning can be seen from student responses or questionnaires. Thus, the implementation of online learning at STMIK Kaputama Binjai must be monitored and evaluated so that the quality of education is maintained. Evaluation of online learning can be seen from student responses or questionnaires by grouping survey results on online learning activities using the K-Means algorithm and clustering method.
\end{abstract}

Keywords: Offline, Online, Virus_Corona, K_Means, Clustering

\section{PENDAHULUAN}

Sampai saat ini, hampir seluruh negara di dunia sedang menghadapi suatu fenomena besar, yaitu terjadinya penyebaran satu virus baru yaitu covid 19 secara cepat yang menyerang tubuh manusia dan dapat menyebabkan kematian. Covid19 merupakan sekumpulan virus yang berasal dari subfamili Orthocronavirinae dalam keluarga Coronaviridae dan ordo Nidovirales (Yunus \& Rezki, 2019). Keberadaan Covid19 membuat masyarakat untuk memberhentikan aktivitas di luar rumah yang semestinya dilakukan seperti pada hari-hari biasa.

Di dunia pendidikan terutama di perguruan tinggi STMIK Kaputama semua dosen atau tenaga pendidik diharuskan untuk mengganti pembelajaran menggunakan E-learning atau melalui media online. E-learning (Daring) adalah Suatu proses pembelajaran jarak jauh dengan cara menggabungkan prinsip-prinsip didalam proses suatu pembelajaran dengan teknologi (Chandrawati, 2019). Pembelajaran yang biasanya dilakukan secara luring sekarang menjadi belajar di rumah dengan menggunakan berbagai macam aplikasi seperti, classroom, zoom, google doc, google form, grup whatsapp maupun ruang guru.

Upaya yang dilakukan oleh perguruan tinggi khususnya di STMIK Kaputama adalah meningkatkan kinerja dosen untuk memperbaiki proses perkuliahan daring, agar pemahaman mahasiswa terhadap materi kuliah meningkat. Dosen memiliki peranan penting dalam mewujudkan layanan perkuliahan secara profesional.

Dosen dituntut mampu merancang dan mendesain pembelajaran daring yang ringan dan efektif. Dengan pembelajaran daring diharapkan akan memberikan kesempatan lebih luas dalam mengeksplorasi materi yang akan diajarkan, namun dosen harus mampu memilih dan membatasi sejauh mana cakupan materinya dan aplikasi yang cocok pada materi dan metode belajar yang digunakan. Dengan demikian, pelaksanaan pembelajaran daring di STMIK Kaputama Binjai harus dimonitoring dan dievaluasi agar mutu pendidikan tetap terjaga. Evaluasi terhadap pembelajaran daring dapat dilihat dari respon atau angket mahasiswa. Hal ini dimaksudkan agar STMIK Kaputama memperoleh umpan balik secara langsung dari mahasiswa sebagai masukan utama proses pendidikan yang diharapkan menjadi luaran dengan potensi unggul. Evaluasi pembelajaran daring berdasarkan respon atau angket mahasiswa diukur berdasarkan aspek keterampilan, pembelajaran, serta sarana dan prasarana.

\section{TINJAUAN TEORITIS \\ Data Mining}

Data mining adalah proses yang menggunakan teknik tatistic, matematika, kecerdasan buatan dan pembelajaran mesin (machine learning) mengekstraksi dan mengidentifikasi informasi yang bermanfaat dan penegtahuan yang terkait dari berbagai database .

\section{Clustering}

Cluster adalah proses algoritma dalam mengelompokan sejumlah data menjadi kelompokkelompok data tertentu (klaster) sedemikian rupa sehingga objek-objek yang tidak serupa menjadi anggota cluster yang lain. Dalam setiap klaster berisikan dengan data yang serupa mungkin.

\section{K-means}

K-means merupakan salah satu metode clustering non hirarki yang berusaha mempartisi data yang ada ke dalam bentuk satu atau lebih cluster. Metode ini mempartisi data ke dalam cluster sehingga data yang memiliki karakteristik yang sama dikelompokkan ke dalam satu cluster yang sama dan data yang mempunyai karateristik yang berbeda 
di kelompokan ke dalam cluster yang lain.

\section{Flowchart}

Flowchart adalah diawali dengan penerimaan input dan diakhiri dengan penampilan output. Flowchart adalah suatu gambaran yang menjelaskan urutan pembaca data, pemrosesan data, penampilan keputusan terhadap data dan penyajian hasil pemrosesan data.

\section{Pembelajaran Daring (Internet Learning)}

Pembelajaran daring merupakan sebuah cara terbaru dengan bentuk penyampaian pembelajaran konvensional dengan memanfaatkan berbagai perangkat elektronik sebagai media pembelajaran dalam menyampaikan materi atau proses pembelajarannya dari jarak jauh tanpa dilakukan dengan face to face tetapi menggunakan media elektronik yang mampu memudahkan mahasiswa untuk belajar kapanpun dan dimanapun.

\section{MATLAB}

MATLAB (Matrix Laboratory) merupakan sebuah program untuk menganalisis dan mengkomputasi data numerik, dan MATLAB juga merupakan suatu bahasa pemrograman matematika lanjutan, yang dibentuk dengan dasar pemikiran yang menggunakan sifat dan bentuk matriks.sebuah bahasa dengan kinerja tinggi untuk komputasi masalah teknik.

\section{PEMBAHASAN}

\section{Perancangan Sistem}

Berdasarkan analisis yang yang dilakukan, penulis akan menggali data untuk dikelompokan dengan menggunakan metode clustering dengan algoritma K-Means, dimana variabel-variabel pada Data Hasil Pembelajaran Daring Berdasarkan survei Dalam Masa Pandemi yang akan diambil untuk penelitian tersebut adalah Prodi, Mata kuliah. Kemudian dari data tersebut di masukan kedalam Matlab sehingga terdapat hasil berupa kesimpulan.

\section{Perancangan Flowchart}

Adapun perancangan proses yang akan dibangun dalam pengelompokkan data hasil pembelajaran daring dalam masa pandemi menggunakan metode clustering nantinya memiliki gambaran flowchart sebagai berikut:



Gambar 1 Flowchart Metode K-Means Clustering

\section{Data Pendukung Penelitian}

Berikut tabel data yang digunakan dalam penelitian ini yaitu sebagai berikut :

Tabel 1 Data Pendukung Penelitian

\begin{tabular}{|c|c|c|c|}
\hline No & $\begin{array}{c}\text { Dose } \\
\mathbf{n}\end{array}$ & Semester & $\begin{array}{c}\text { Jawaba } \\
\mathbf{n}\end{array}$ \\
\hline 1 & ACF & 5 & 5 \\
\hline 2 & AMP & 1 & 5 \\
\hline 3 & ARS & 5 & 4 \\
\hline 4 & ASG & 1 & 4 \\
\hline 5 & ASH & 3 & 4 \\
\hline 6 & AUA & 5 & 5 \\
\hline 7 & BSG & 5 & 4 \\
\hline 8 & DRM & 1 & 4 \\
\hline 9 & DRS & 3 & 4 \\
\hline 10 & FYM & 5 & 3 \\
\hline 11 & HMS & 1 & 4 \\
\hline 12 & HTM & 7 & 5 \\
\hline 13 & HUK & 5 & 4 \\
\hline 14 & IGP & 7 & 4 \\
\hline 15 & IMG & 5 & 4 \\
\hline 16 & IML & 5 & 4 \\
\hline 17 & IND & 1 & 4 \\
\hline 18 & IWT & 1 & 4 \\
\hline 19 & JNS & 1 & 4 \\
\hline 20 & KAS & 3 & 4 \\
\hline
\end{tabular}


Keterangan :

$1=$ Sangat Kurang

$2=$ Kurang

$$
3=\text { Cukup }
$$

4 = Baik

$5=$ Sangat Baik

\section{Transformasi Data}

Dari Data yang ada maka dapat dilakukan inisialisasi data sesuai dengan kebutuhan variable sebagai berikut :

Tabel.2 Transformasi Data dengan Kriteria Dosen

\begin{tabular}{|c|c|}
\hline Kode & $\begin{array}{c}\text { Nama } \\
\text { Dosen(Insial) }\end{array}$ \\
\hline 1 & $\mathrm{ACF}$ \\
\hline 2 & AMP \\
\hline 3 & ARS \\
\hline 4 & $\mathrm{ASG}$ \\
\hline 5 & $\mathrm{ASH}$ \\
\hline 6 & AUA \\
\hline 7 & BSG \\
\hline 8 & DRM \\
\hline 9 & DRS \\
\hline 10 & FYM \\
\hline 11 & HMS \\
\hline 12 & HTM \\
\hline 13 & HUK \\
\hline 14 & IGP \\
\hline 15 & IMG \\
\hline 16 & IML \\
\hline 17 & IND \\
\hline 18 & IWT \\
\hline 19 & JNS \\
\hline 20 & KAS \\
\hline 21 & KLB \\
\hline 22 & MAS \\
\hline 23 & MDS \\
\hline 24 & MIA \\
\hline 25 & MPU \\
\hline 26 & $\mathrm{NOV}$ \\
\hline 27 & NTJ \\
\hline 28 & NUR \\
\hline 29 & RLB \\
\hline 30 & RUS \\
\hline 31 & SCR \\
\hline 32 & SSY \\
\hline 33 & TMN \\
\hline 34 & TNL \\
\hline 35 & TRP \\
\hline 36 & YMT \\
\hline 37 & YUS \\
\hline 38 & ZFS \\
\hline 39 & ZFT \\
\hline 40 & LNA \\
\hline
\end{tabular}

Tabel 3 Transformasi Data dengan Kriteria Semester

\begin{tabular}{|c|l|}
\hline Ko & \multicolumn{1}{|c|}{ Semester } \\
\cline { 2 - 3 } de & \multicolumn{1}{|c|}{ berdasarkan MTK } \\
\hline 1 & Pendidikan Pancasila \\
\hline 1 & Bhs Inggris 1 \\
\hline 1 & Akuntansi Dasar \\
\hline 1 & Kalkulus \\
\hline 1 & Konsep Sistem Informasi \\
\hline 1 & Pengantar Teknologi Informasi \\
\hline 1 & Algoritma Pemograman \\
\hline 1 & Pengantar Manajemen \\
\hline 3 & Pendidikan Agama \\
\hline 3 & Struktur Data \\
\hline 3 & Matematika Diskrit \\
\hline 3 & Teknik Riset Operasi \\
\hline 3 & Sistem Informasi Manajemen \\
\hline 3 & Sistem Basis Data 2 \\
\hline 3 & Pemograman Web 1 \\
\hline 5 & Bahasa Indonesia \\
\hline 5 & Etika Profesi \\
\hline 5 & Pemograman Multimedia \\
\hline 5 & Organisasi dan Arsitektur \\
\hline 5 & Sistem Informasi Akuntansi \\
\hline 5 & Pemograman Visual 2 \\
\hline 5 & Elektronik Bisnis \\
\hline 7 & PKL \\
\hline 7 & Data Mining \\
\hline 7 & Sistem Pakar \\
\hline 7 & Sistem Pendukung Keputusan \\
\hline 7 & Keamanan Sistem Informasi \\
\hline 7 & Pilihan 1 \\
\hline 7 & Pilihan 2 \\
\hline & \\
\hline & \\
\hline & \\
\hline 1
\end{tabular}

Tabel 4 Transformasi Data Jawaban Responden

\begin{tabular}{|c|l|}
\hline Kode & $\begin{array}{l}\text { Jenis } \\
\text { esponden }\end{array}$ \\
\hline 5 & Sangat Baik \\
\hline 4 & Baik \\
\hline 3 & Cukup \\
\hline 2 & Kurang \\
\hline 1 & Sangat Kurang \\
\hline
\end{tabular}

\section{Perhitungan Metode Cluster}

Pengelompokan Hasil Pembelajaran Mahasiswa Selama Masa Pandemik Covid 19 ini dinyatakan dalam suatu variable-variabel yang independen yaitu Dosen (X), Semester (Y) dan Jawaban (Z). 
Tabel 5 Transformasi Data Berdasarkan Inisial yang dibentuk

\begin{tabular}{|c|c|c|c|}
\hline $\begin{array}{l}\mathbf{N} \\
\mathbf{0}\end{array}$ & $\begin{array}{c}\text { Dose } \\
\text { n }\end{array}$ & $\begin{array}{c}\text { Semester } \\
\text { Brdsrkn } \\
\text { MTK }\end{array}$ & $\begin{array}{c}\text { Jawaba } \\
\mathbf{n}\end{array}$ \\
\hline 1 & 1 & 5 & 5 \\
\hline 2 & 2 & 1 & 5 \\
\hline 3 & 3 & 5 & 4 \\
\hline 4 & 4 & 1 & 4 \\
\hline 5 & 5 & 3 & 4 \\
\hline 6 & 6 & 5 & 5 \\
\hline 7 & 7 & 5 & 4 \\
\hline 8 & 8 & 1 & 4 \\
\hline 9 & 9 & 3 & 4 \\
\hline 10 & 10 & 5 & 3 \\
\hline 11 & 11 & 1 & 4 \\
\hline 12 & 12 & 7 & 5 \\
\hline 13 & 13 & 5 & 4 \\
\hline 14 & 14 & 7 & 4 \\
\hline 15 & 15 & 5 & 4 \\
\hline 16 & 16 & 5 & 4 \\
\hline 17 & 17 & 1 & 4 \\
\hline 18 & 18 & 1 & 4 \\
\hline 19 & 19 & 1 & 4 \\
\hline 20 & 20 & 3 & 4 \\
\hline
\end{tabular}

Melakukan perhitungan data menggunakan algoritma KMeans Clustering.

ITERASI $=1$

Centorid $1=1,5,5$

Centroid $2=2,1,5$

Centroid $3=3,5,4$

Bagian A

$\mathrm{K}=3$, Centorid $1=\{1,5,5\}$ Centroid $2=\{2,1,5\}$ Centroid $3=\{3,5,4\}$

$\operatorname{JarakdariC} 1(\mathrm{x})=$

$\sqrt{(1-1)^{2}+(5-5)^{2}+(5-5)^{2}}=0$

JarakdariC2 $(\mathrm{y})=$

$\sqrt{(1-2)^{2}+(5-1)^{2}+(5-5)^{2}}=4$

$\operatorname{JarakdariC} 3(\mathrm{z})=\sqrt{(1-3)^{2}+(5-5)^{2}+(5-4)^{2}} 2$

Bagian B

$\mathrm{K}=3$, Centorid $1=\{1,5,5\}$ Centroid $2=\{2,1,5\}$ Centroid $3=\{3,5,4\}$

$\operatorname{JarakdariC} 1(\mathrm{x})=\sqrt{(2-1)^{2}+(1-5)^{2}+(5-5)^{2}}=4$ $\operatorname{JarakdariC} 2(\mathrm{y})=\sqrt{(2-2)^{2}+(1-1)^{2}+(5-5)^{2}}=$ 0

$\operatorname{JarakdariC} 3(\mathrm{z}) \sqrt{(2-3)^{2}+(1-5)^{2}+(5-4)^{2}}=4$

Bagian C

$\mathrm{K}=3$, Centorid $1=\{1,5,5\}$ Centroid $2=\{2,1,5\}$ Centroid $3=\{3,5,4\}$

$\operatorname{JarakdariC} 1(\mathrm{x})=\sqrt{(3-1)^{2}+(5-5)^{2}+(4-5)^{2}} 2$

JarakdariC2 $(y) \sqrt{(3-2)^{2}+(5-1)^{2}+(4-5)^{2}} 4$

$\operatorname{JarakdariC} 3(\mathrm{z}) \sqrt{(3-3)^{2}+(5-5)^{2}+(4-4)^{2}}=0$

Dan seterusnya.
Tabel 6 Hasil Penentuan Group 1

\begin{tabular}{|c|c|c|c|c|c|c|c|}
\hline \multirow[t]{2}{*}{$\begin{array}{l}\mathbf{N} \\
\mathbf{0}\end{array}$} & $\begin{array}{c}\text { Kela } \\
\mathbf{S}\end{array}$ & $\begin{array}{c}\text { MT } \\
\text { K }\end{array}$ & $\begin{array}{c}\text { Ja } \\
\text { wa } \\
\text { ban }\end{array}$ & $\begin{array}{c}\mathbf{J r} \\
\mathbf{k} \\
\mathbf{d a} \\
\mathbf{r i} \\
\end{array}$ & $\begin{array}{c}\mathbf{J r} \\
\mathbf{k} \\
\mathbf{d a} \\
\mathbf{r i} \\
\end{array}$ & $\begin{array}{c}\text { Jrk } \\
\text { dar } \\
\text { i }\end{array}$ & \multirow[t]{2}{*}{$\begin{array}{c}\text { Gr } \\
\text { ou } \\
\text { p }\end{array}$} \\
\hline & $\mathbf{X}$ & $\mathbf{Y}$ & $\mathbf{Z}$ & C1 & $\mathrm{C} 2$ & C3 & \\
\hline 1 & 1 & 5 & 5 & 0 & 4 & 2 & 1 \\
\hline 2 & 2 & 1 & 5 & 4 & 0 & 4 & 2 \\
\hline 3 & 3 & 5 & 4 & 2 & 4 & 0 & 3 \\
\hline 4 & 4 & 1 & 4 & 5 & 2 & 4 & 2 \\
\hline 5 & 5 & 3 & 4 & 5 & 4 & 3 & 3 \\
\hline 6 & 6 & 5 & 5 & 5 & 6 & 3 & 3 \\
\hline 7 & 7 & 5 & 4 & 6 & 6 & 4 & 3 \\
\hline 8 & 8 & 1 & 4 & 8 & 6 & 6 & 3 \\
\hline 9 & 9 & 3 & 4 & 8 & 7 & 6 & 3 \\
\hline 10 & 10 & 5 & 3 & 9 & 9 & 7 & 3 \\
\hline 11 & 11 & 1 & 4 & 11 & 9 & 8 & 3 \\
\hline 12 & 12 & 7 & 5 & 11 & 12 & 9 & 3 \\
\hline 13 & 13 & 5 & 4 & 12 & 12 & 10 & 3 \\
\hline 14 & 14 & 7 & 4 & 13 & 14 & 11 & 3 \\
\hline 15 & 15 & 5 & 4 & 14 & 13 & 12 & 3 \\
\hline 16 & 16 & 5 & 4 & 15 & 14 & 13 & 3 \\
\hline 17 & 17 & 1 & 4 & 17 & 15 & 14 & 3 \\
\hline 18 & 18 & 1 & 4 & 17 & 16 & 15 & 3 \\
\hline 19 & 19 & 1 & 4 & 18 & 17 & 16 & 3 \\
\hline 20 & 20 & 3 & 4 & 19 & 18 & 17 & 3 \\
\hline
\end{tabular}

Keterangan:

1. Jika pada Centroid 1 lebih kecil maka hasil cluster masuk pada group 1

2. Jika pada Centroid 2 lebih kecil maka hasil cluster masuk pada group 2

3. Jika pada Centroid 3 lebih kecil maka hasil cluster masuk pada group 
Tabel 7 Hasil Penentuan Group 2

\begin{tabular}{|c|c|c|c|c|c|c|c|}
\hline \multirow{2}{*}{$\begin{array}{l}\mathbf{N} \\
\mathbf{0}\end{array}$} & $\begin{array}{c}\text { Kela } \\
\mathbf{S}\end{array}$ & $\begin{array}{c}\text { MT } \\
\text { K }\end{array}$ & $\begin{array}{c}\text { Jawab } \\
\text { an }\end{array}$ & $\begin{array}{c}\text { Jrk } \\
\text { dari }\end{array}$ & $\begin{array}{c}\text { Jrk } \\
\text { dari }\end{array}$ & $\begin{array}{c}\text { Jrk } \\
\text { dari }\end{array}$ & \multirow{2}{*}{$\begin{array}{c}\text { Gro } \\
\text { up }\end{array}$} \\
\hline & $\mathbf{X}$ & $\mathbf{Y}$ & $\mathbf{Z}$ & C1 & $\mathrm{C2}$ & C3 & \\
\hline 1 & 1 & 5 & 5 & 5 & 9 & 17 & 1 \\
\hline 2 & 2 & 1 & 5 & 6 & 9 & 15 & 1 \\
\hline 3 & 3 & 5 & 4 & 3 & 7 & 15 & 1 \\
\hline 4 & 4 & 1 & 4 & 5 & 7 & 13 & 1 \\
\hline 5 & 5 & 3 & 4 & 2 & 5 & 12 & 1 \\
\hline 6 & 6 & 5 & 5 & 0 & 4 & 12 & 1 \\
\hline 7 & 7 & 5 & 4 & 1 & 3 & 11 & 1 \\
\hline 8 & 8 & 1 & 4 & 5 & 5 & 9 & 1 \\
\hline 9 & 9 & 3 & 4 & 4 & 2 & 8 & 2 \\
\hline 10 & 10 & 5 & 3 & 4 & 0 & 8 & 2 \\
\hline 11 & 11 & 1 & 4 & 6 & 4 & 6 & 2 \\
\hline 12 & 12 & 7 & 5 & 6 & 3 & 8 & 2 \\
\hline 13 & 13 & 5 & 4 & 7 & 3 & 6 & 2 \\
\hline 14 & 14 & 7 & 4 & 5 & 5 & 7 & 2 \\
\hline 15 & 15 & 5 & 4 & 9 & 5 & 4 & 3 \\
\hline 16 & 16 & 5 & 4 & 10 & 6 & 4 & 3 \\
\hline 17 & 17 & 1 & 4 & 12 & 8 & 0 & 3 \\
\hline 18 & 18 & 1 & 4 & 12 & 9 & 1 & 3 \\
\hline 19 & 19 & 1 & 4 & 14 & 9 & 2 & 3 \\
\hline 20 & 20 & 3 & 4 & 14 & 10 & 4 & 3 \\
\hline
\end{tabular}

Group1(lama)adalah $=\{1,2,3,2,3,3,3,3,3,3,3,3,3,3,3,3,3,3$, $33\}$

Group2(baru)adalah $=\{1,1,1,1,1,1,1,1,2,2,2,2,2,2,3,3,3,3,3$ ,3\}

Terjadi perubahan group maka dilanjutkan ke iterasi berikutnya.

\section{Tabel III.8 Hasil Penentuan Group 3}

\begin{tabular}{|c|c|c|c|c|c|c|c|}
\hline \multirow[t]{2}{*}{ No } & $\begin{array}{c}\text { Kel } \\
\text { as }\end{array}$ & $\begin{array}{c}\text { M } \\
\text { TK }\end{array}$ & $\begin{array}{c}\text { Ja } \\
\text { wa } \\
\text { ban }\end{array}$ & $\begin{array}{c}\mathbf{J r} \\
\mathbf{k} \\
\mathbf{d a} \\
\mathbf{r i}\end{array}$ & $\begin{array}{c}\mathbf{J r} \\
\mathbf{k} \\
\mathbf{d a} \\
\mathbf{r i}\end{array}$ & $\begin{array}{c}\text { Jrk } \\
\text { dari }\end{array}$ & \multirow[t]{2}{*}{$\begin{array}{c}\text { Grou } \\
\text { p }\end{array}$} \\
\hline & $\mathbf{X}$ & $\mathbf{Y}$ & $\mathbf{Z}$ & C1 & $\mathrm{C2}$ & C3 & \\
\hline 1 & 1 & 5 & 5 & 8 & 11 & 13 & 1 \\
\hline 2 & 2 & 1 & 5 & 6 & 12 & 13 & 1 \\
\hline 3 & 3 & 5 & 4 & 6 & 9 & 11 & 1 \\
\hline 4 & 4 & 1 & 4 & 4 & 10 & 12 & 1 \\
\hline 5 & 5 & 3 & 4 & 4 & 8 & 10 & 1 \\
\hline 6 & 6 & 5 & 5 & 5 & 6 & 8 & 1 \\
\hline 7 & 7 & 5 & 4 & 4 & 5 & 7 & 1 \\
\hline 8 & 8 & 1 & 4 & 0 & 7 & 8 & 1 \\
\hline 9 & 9 & 3 & 4 & 5 & 2 & 6 & 2 \\
\hline 10 & 10 & 5 & 3 & 5 & 3 & 5 & 2 \\
\hline 11 & 11 & 1 & 4 & 14 & 6 & 6 & 2 \\
\hline 12 & 12 & 7 & 5 & 7 & 0 & 2 & 2 \\
\hline 13 & 13 & 5 & 4 & 6 & 2 & 2 & 2 \\
\hline 14 & 14 & 7 & 4 & 6 & 0 & 2 & 2 \\
\hline
\end{tabular}

\begin{tabular}{|c|c|c|c|c|c|c|c|}
\hline 15 & 15 & 5 & 4 & 8 & 4 & 2 & 3 \\
\hline 16 & 16 & 5 & 4 & 9 & 5 & 2 & 3 \\
\hline 17 & 17 & 1 & 4 & 9 & 8 & 6 & 3 \\
\hline 18 & 18 & 1 & 4 & 10 & 9 & 7 & 3 \\
\hline 19 & 19 & 1 & 4 & 11 & 9 & 8 & 3 \\
\hline 20 & 20 & 3 & 4 & 12 & 9 & 7 & 3 \\
\hline
\end{tabular}

Setelah dilakukan perhitungan menggunakan cluster k-means yang ada, pada iterasi 3 terjadi persamaan pada iterasi 2 dan tidak ada data yang berpindah ataupun berubah group sehingga perhitungan dapat dihentikan.

Group2(lama)adalah $=\{1,1,1,1,1,1,1,1,2,2,2,2,2,2,3,3,3,3$, $3\}$

Group3(baru)adalah $=\{1,1,1,1,1,1,1,1,2,2,2,2,2,2,3,3,3,3,3$ \}

\section{Rancangan Interface (Antar Muka)}

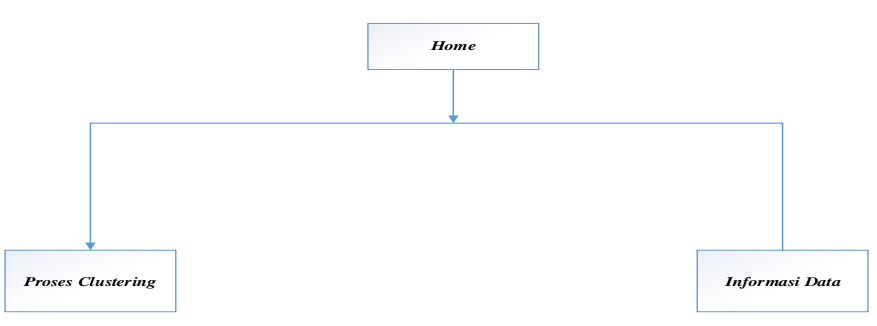

Gambar 2 Diagram Hirearki Interface Antar Muka Data Mining

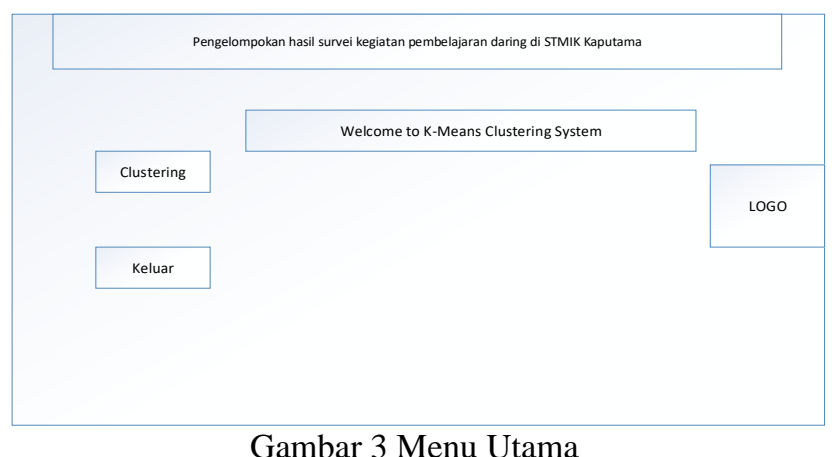

Gambar 3 Menu Utama

\section{Halaman Proses Cluster}

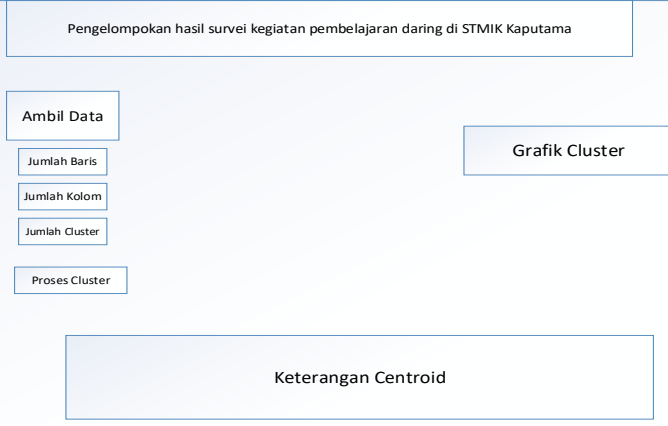

Menu utama

Gambar 4 Halaman Proses Cluster 


\section{Halaman Info}

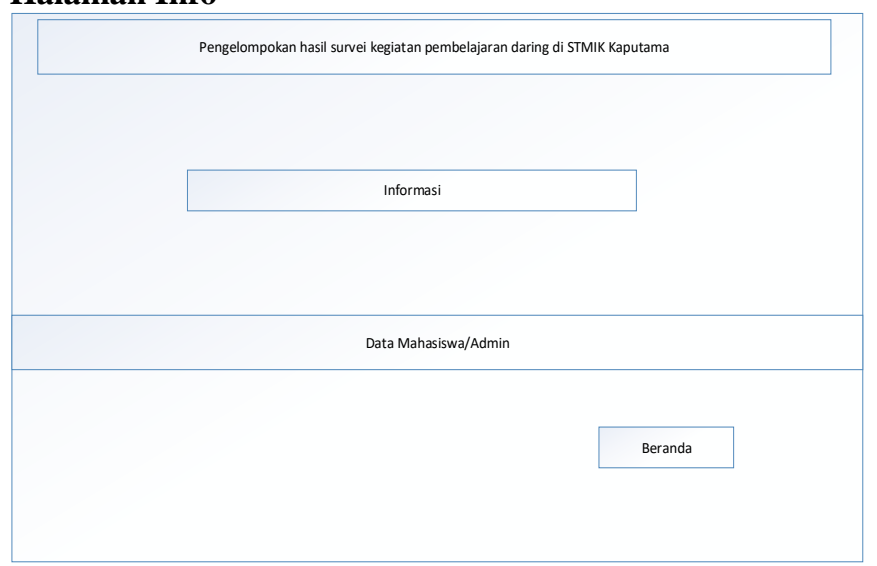

Gambar 5 Halaman Info

\section{HASIL DAN PENGUJIAN}

\section{Implementasi}

Implementasi merupakan kegiatan dimana data-data yang sudah di transformasikan diterapkan kedalam pemrograman yang digunakan dan diproses sesuai metode clustering dengan algoritma k-means, sehingga dapat diketahui sejauh mana kinerja system dalam mengolah data dan dihasilkan informasi sesuai dengan kebutuhan pengguna.

\section{Hasil Uji Coba Program}

\section{Halaman Home}

Form Home ini berisi menu utama yaitu tampilan logo, judul aplikasi,button cluster dan button keluar.

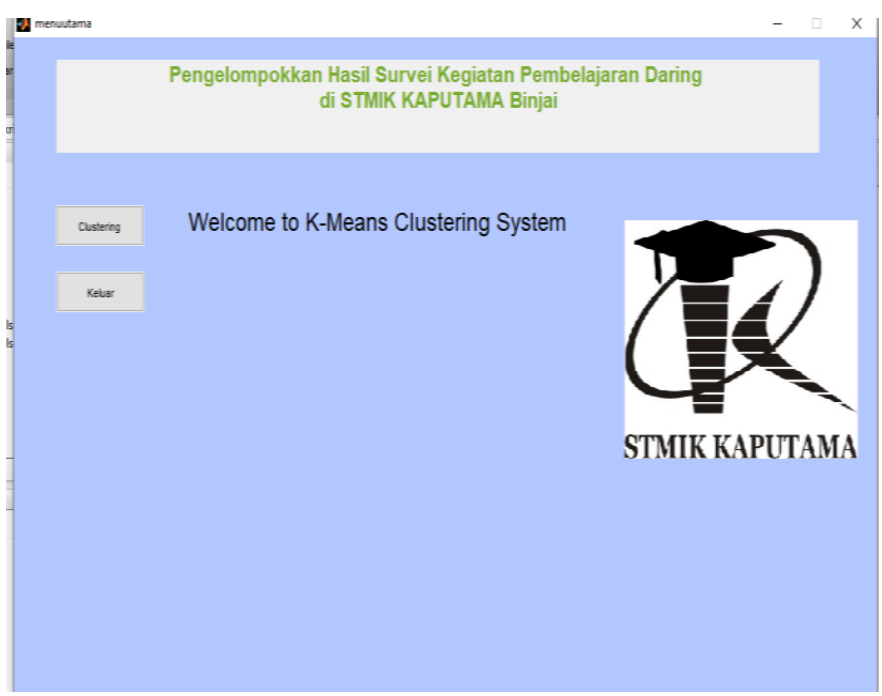

Gambar 6 Menu Utama

\section{Halaman Proses Cluster}

Pada halaman ini akan terlihat keseluruhan proses data mining sampai pada munculnya grafik dan serta keterangan centroid sebagai hasil dari perhitungan menggunakan metode clustering dengan algoritma kmeans.

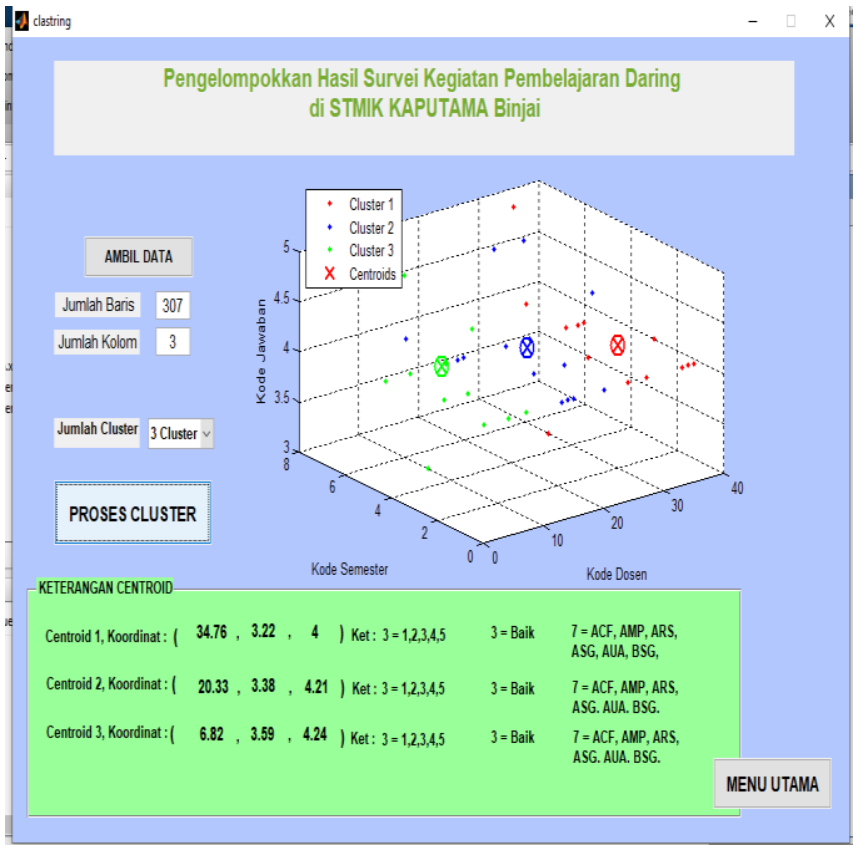

Gambar 7 Halaman Proses Cluster

Dari hasil proses cluster diatas dapat dijumlahkan masingmasing group yaitu sebagai berikut :

Titik Pusat :

$\begin{array}{lccl}\text { Cluster 1 : } & 34,76 & 3,22 & 4 \\ \text { Cluster 2 : } & 20,33 & 3,38 & 4,2 \\ \text { Cluster 3 : } & 6,82 & 3,59 & 4,24\end{array}$

\section{Halaman Info}

Pada gambar ini akan menunjukkan halaman info pada program yang akan dibuat peneliti. Berikut gambar halaman info yaitu sebagai berikut :

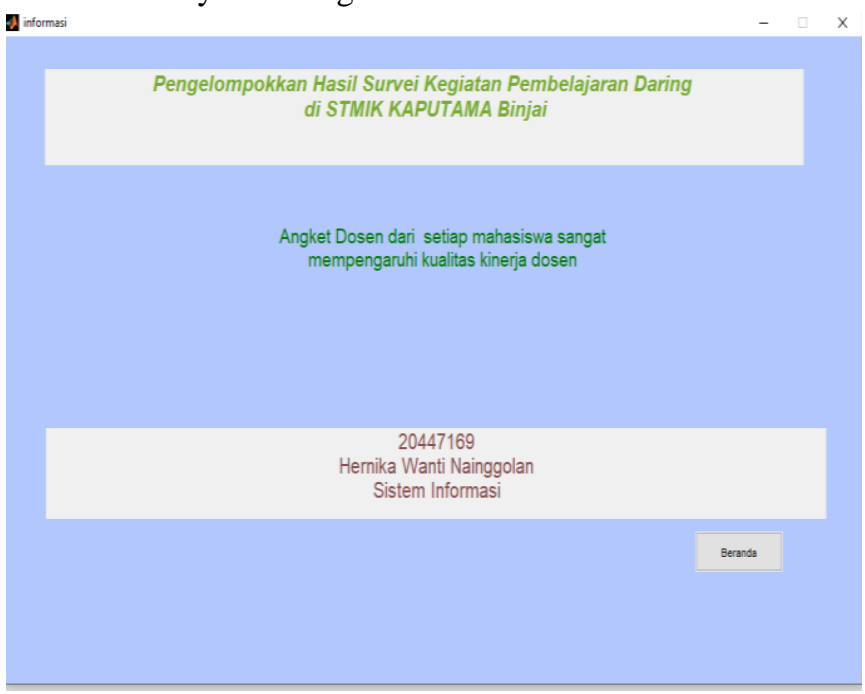

Gambar 8 Halaman Info

\section{KESIMPULAN}

Berdasarkan hasil perancangan dan pembuatan program pengelempokan hasil survei kegiatan pembelajaran daring menggunakan algoritma K-means dapat diambil kesimpulan sebagai berikut:

1. Penerapan data mining untuk pengelompokan hasil survei kegiatan pembelajaran daring dengan menggunakan metode clustering dapat diterapkan 
dan menghasilkan inforrmasi dengan menggunakan Matlab GUI.

2. Berdasarkan proses cluster yang telah dilakukan dalam pengelompokan datahasil survei kegiatan pembelajaran daring maka dapat disimpulkan bahwa dosen yang unggul dalam kegiatan daring berdasarkan hasil survei yang dilakukan adalah ACF, AMP, ARS, ASG, AUA, BSG dan mendapat kriteria jawaban baik dari semua angket dosen yang dinilai oleh mahasiswa semester 3 (tiga).

\section{DAFTAR PUSTAKA}

[1] Bagus.2020. Jurnal Problematika Pembelajaran Daring, Denpasar

[2] Dr.Eng Ags Naba.2017. Jurnal Pengertian GUI.Yogyakarta

[3] Relita, dkk.2019.Time Series Data Mining.Jakarta

[4] Prasetiyo.2017.Data Mining .Yogyakarta.

[5] Sugiono, dkk.2019.Jurnal E-earning padapengantar Teknologi Informasi, Yogyakarta.

[6] Wikipedia.org/wiki/MATLAB diakses pada tanggal 24 juni 2021 